\title{
DEMOCRATIC IMPLICATIONS ARISING FROM THE INTERSECTION OF INVESTMENT ARBITRATION AND HUMAN RIGHTS
}

\author{
BARNALI CHOUDHURY*
}

In the last two decades, investors have taken advantage of investment arbitration mechanisms in investment treaties to challenge state regulations, often implicating human rights issues. This article examines the conflict between states' human rights obligations and their obligations under investment treaties. The first part of the article examines common obligations arising under investment treaties and the investment arbitration process created by the treaties. In the second part, the author examines the way in which investment treaties and arbitrations impact human rights concerns. In particular, the author reviews a number of human rights, including the right to water, the right to health, and rights related to culture. The author also examines common provisions of investment treaties that are particularly problematic in terms of human rights issues: expropriation and fair and equitable treatment.

The author analyzes the democratic deficit inherent in the creation of investment treaties and the structure of investment arbitration, concluding that investment treaties generally lack true democratic consent, and that investment arbitration lacks sufficient transparency and protection for minority rights to reflect true democratic principles. The article concludes with suggestions for reform to address the democratic deficit of investment arbitration through both the provisions of investment treaties and the structure and procedure of arbitration.
Au cours des deux dernières décennies, les investisseurs ont profité de mécanismes d'arbitrage des accords d'investissement pour remettre en question les règlements de l'État, impliquant souvent des questions de droits de la personne. Cet article examine le conflit entre les obligations des États en termes de droits de la personne et leurs obligations en vertu des accords d'investissement. La première partie de l'article porte sur les obligations communes découlant des accords d'investissement et du processus d'arbitrage créé par ces accords. Dans la seconde partie, l'auteur examine de quelle manière les accords et l'arbitrage influent sur les questions de droits de la personne. Tout particulièrement, l'auteur étudie un certain nombre de droits de la personne, incluant le droit à l'eau, le droit à la santé et les droits liés à la culture. L'auteur étudie aussi les dispositions communes aux accords d'investissement qui sont particulièrement problématiques en termes de droits de la personne, notamment l'expropriation et le traitement juste et équitable.

L'auteur analyse le déficit démocratique inhérent à la création des accords d'investissement et à la structure de l'arbitrage, concluant que le consentement démocratique manque souvent à ces accords et que l'arbitrage n'est pas suffisamment transparent et ne protège pas les droits des minorités pour refléter fidèlement les principes démocratiques. L'article termine avec des suggestions de réforme abordant le déficit démocratique de l'arbitrage sur l'investissement au moyen, à la fois, des dispositions des accords et de la structure de la procédure d'arbitrage.

\section{TABLE OF CONTENTS}

I. AN INTRODUCTION TO INVESTMENT TREATIES:

OBLigAtions AND THE ARBitration Process . . . . . . . . . . . 985

A. InVESTMENT TREATy OBLIGATIONS $\ldots \ldots \ldots \ldots \ldots \ldots \ldots . \ldots 95$

B. InVESTMENT ARBITRATION . . . . . . . . . . . . . . . . 987

II. HuMAN RightS IMPLICATIONS OF INVESTMENT ARBitRATIONS . . . . . . 989

A. INVESTMENT ARBITRATIONS IMPLICATING

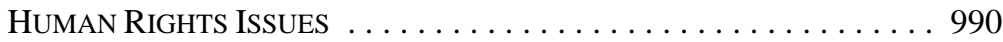

B. INVESTMENT TREATY OBLIGATIONS THAT LiMit THE

PRotection of HuMAN Rights . . . . . . . . . . . . . . . . . . . . . . 994 
III. ThE FAILURE OF INVESTMENT ARBitRATION TO ALIGN WITH

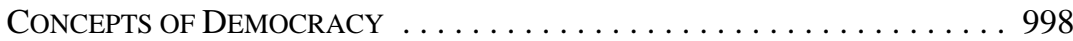

A. INVESTMENT TREATIES DO NOT NECESSARILY

REFLECT DEMOCRATIC CONSENT . . . . . . . . . . . . . . 999

B. The PROCESS OF INVESTMENT ARBitRATION IS

DEMOCRATICALLY DEFICIENT . . . . . . . . . . . . . . . . . . . . . . . . 1001

IV. INFUSING DEMOCRATIC PRINCIPLES INTO

INVESTMENT ARBITRATION . . . . . . . . . . . . . . . . . . . 1003

A. REDUCING THE SCOPE OF

INVESTMENT ARBITRATION . . . . . . . . . . . . . . . . . . . . . . . . 1003

B. INFUSING DEMOCRATIC PRINCIPLES INTO THE

INVESTMENT DisPUTE RESOLUTION PROCESS . . . . . . . . . . . . . . 1005

V. CONCLUSION . . . . . . . . . . . . . . . . . . . . . . . . . . . . . . . 1007

Despite the public criticism surrounding the failed attempt to create a multilateral foreign investment agreement, codified rules governing foreign investment have continued to flourish in relative obscurity. Today, a patchwork of investment treaties and preferential trade agreements dictate the governance of foreign investment. ${ }^{1} \mathrm{~A}$ common feature of these treaties is a dispute settlement mechanism that allows investors to directly initiate lawsuits against host states. In the past two decades, investors have used this mechanism to challenge an array of state regulations thought to be interfering with investor rights before investment arbitral tribunals. In so doing, they have often implicated human rights issues.

The effect of these decisions, and their implication on human rights issues, has been to curtail a state's democratic expression by countering its sovereign decision-making authority. State parties to investment agreements can no longer protect or promote human rights issues without concern that the regulation will be found to constitute an interference with the state's investment treaty obligations. Investment arbitration's primary focus on investment rights has accordingly shifted the boundary between the public good and private interest in favour of the private interests of investors, resulting in profound implications for democracy and human rights.

In part, the democracy critique of investment arbitration arises from the democratically bereft process that characterizes investment arbitration. Modeled after private arbitration, the opaque decision-making process is propelled by unaccountable decision-makers whose decisions cannot be corrected by any meaningful checks or balances. Charges of democratic shortcomings also arise from the human rights issues entangled in investment treaty disputes. In effect, investment arbitration has become involved in the adjudication of society's core values without the input from the affected society. Consequently, to reflect society's stakehold in the human rights issues implicated in investment arbitration, the process needs to better reflect principles of democracy. 
Part I of this article begins by introducing the obligations contained in and the arbitration process of investment treaties. Part II then explores the human rights implications of investment arbitration by surveying, first, investment treaty disputes with human rights implications, and second, provisions of investment treaties with the ability to hamper human rights goals. Part III continues by examining the reasons for investment arbitration's inability to align with concepts of democracy. Finally, Part IV discusses possible solutions for instilling greater democracy into investment arbitration.

\section{AN INTRODUCTION TO INVESTMENT TREATIES: Obligations and the Arbitration Process}

Today's foreign investment economy is shaped by the almost 3,000 international investment treaties that pervade the modern world. ${ }^{2}$ Over 2,500 of these treaties are in the form of bilateral investment treaties: treaties that are entered into by two states to govern foreign investment in the contracting states. ${ }^{3}$ The remainder consists of preferential trade and regional trade agreements: treaties that establish free trade areas in addition to governing foreign investment. ${ }^{4}$ Together these treaties govern significant aspects of global foreign investment, the importance of which continues to grow. In 2006, global foreign direct investment inflows represented a value of almost US\$1,306 billion and foreign investment inflows increased in both developed and developing countries, as well as in transition economies. ${ }^{5}$

However, despite the lack of harmonization among investment treaties, the treaties generally all contain a number of standard features. In particular, the treaties contain substantive state obligations and a dispute resolution forum to determine whether the state has met its substantive obligations.

\section{A. InVESTMENT Treaty Obligations}

Investment treaties create state obligations for the protection and promotion of foreign investments. ${ }^{6}$ The purpose of the treaties is to shield foreign investments and investors from state interference and state regulation. ${ }^{7}$ Notably, the crux of the state obligation turns on the definition of investment. In most treaties, the term "investment" is defined very broadly, thereby encompassing all economic activity within the scope of the definition. ${ }^{8}$

$2 \quad$ Ibid.

$3 \quad$ Ibid. For an overview of bilateral investment treaties, see Rudolf Dolzer \& Margrete Stevens, Bilateral Investment Treaties (The Hague: Martinus Nijhoff, 1995); M. Sornarajah, The International Law on Foreign Investment, 2d ed. (Cambridge: Cambridge University Press, 2004) at 2.

$4 \quad$ World Investment Report, ibid. For an overview of preferential trade agreements see Rudolf Adlung \& Martin Molinuevo, “Bilateralism in Services Trade: Is There Fire Behind the (BIT-) Smoke?” WTO Staff Working Paper No. ERSD-2008-01 (2008) at 3, online: Social Science Research Network <http:// papers.ssrn.com/sol3/papers.cfm?abstract_id=1086304>.

$5 \quad$ World Investment Report, ibid. at xv.

$6 \quad$ Sornarajah, supra note 3 at 218, n. 35; Dolzer \& Stevens, supra note 3 at 21.

7 Gus Van Harten, Investment Treaty Arbitration and Public Law (Oxford: Oxford University Press, 2007) at $80-81$.

8 For example, American treaties specify that investments comprise "every kind of investment owned or controlled directly or indirectly by that national or company” and Swiss treaties specify that investments encompass "toutes les catégories d'avoirs": see e.g. Treaty Between The Government Of The United 
Consequently, where states are prohibited from interfering with "every kind of asset," as United Kingdom and German treaties define the term "investment," foreign investments can be protected from a vast array of governmental activity. ${ }^{9}$

Most investment treaties also contain four core state obligations. First, states must provide investors and investments with national treatment. ${ }^{10}$ National treatment obliges states to treat foreign investors and investments no less favourably than domestic investors or investments, essentially prohibiting discriminatory treatment of foreign investors. Second, states must accord investors and investments with Most Favoured Nation (MFN) treatment. MFN treatment requires states to treat investors no less favourably than investors from a third party state or a non-party state. ${ }^{11}$ Accordingly, if a state extends an advantage to an investor from country X, MFN treatment requires the state to extend that same advantage to the investor from the contracting state. Third, states must accord "fair and equitable treatment" to foreign investors. ${ }^{12}$ Pursuant to this requirement, states must accord investors a minimum standard of treatment, generally the standard required by international law, regardless of the standard of treatment it accords its domestic investors. ${ }^{13}$ Finally, states are prohibited from directly or indirectly expropriating investments without compensation. ${ }^{14}$

These core obligations along with any other obligations provided for in the treaties define the normative content of the treaty. However, the interpretations of the ambiguously worded obligations determine the impact of the treaties. ${ }^{15}$ For this reason, the dispute resolution provision of an investment treaty is likely its most important feature.

States Of America And The Government Of The Republic Of Bolivia Concerning The Encouragement And Reciprocal Protection Of Investment, 17 April 1998, 12943 T.I.A.S. 1, art. 1; Accord entre la Confédération Suisse et la République fédérale et démocratique d'Ethiopie concernant la promotion et la protection réciproque des investissements, 26 June 1998, 2001 Recueil Officiel des Lois Federales 1967, art. 1.

Agreement between the Government of the United Kingdom of Great Britain and Northern Ireland and the Government of the Sultanate of Oman for the Promotion and Protection of Investments, 25 November 1995, U.K.T.S. 1996 No. 99, art. 1; Agreement Between the Kingdom of Cambodia and The Federal Republic of Germany Concerning the Encouragement and Reciprocal Protection of Investments, 15 February 1999, 2183 U.N.T.S. 130, art. 1.

10 See e.g. North American Free Trade Agreement Between the Government of Canada, the Government of the United Mexican States and the Government of the United States of America, 17 December 1992, Can. T.S. 1994 No. 2, art. 1102 (entered into force 1 January 1994) [NAFTA]. See also Treaty Between the Government of the United States of America and the Government of the Republic of Honduras Concerning the Encouragement and Reciprocal Protection of Investment, 1 July 1995, Senate Treaty Doc. No. 106-27, art. II(1).

11 See e.g. NAFTA, ibid., art. 1103, or the Agreement between the Swedish Government and the Macedonian Government on the Promotion and Reciprocal Protection of Investments, 7 May 1998, Sveriges internationella överenskommelser 1998 No. 25, art. 3(1).

12 See e.g. NAFTA, ibid., art. 1105 or Treaty between the United States of America and the Republic of Turkey Concerning the Reciprocal Encouragement and Protection of Investments, 3 December 1985, Senate Treaty Doc. No. 99-19, art. II(3).

13 For an overview of "fair and equitable" treatment, see Part II.B.2, below.

14 Dolzer \& Stevens, supra note 3 at 97; Organisation for Economic Co-operation and Development (OECD) Directorate for Financial and Enterprise Affairs, “'Indirect Expropriation' and the 'Right To Regulate’ in International Investment Law” Working Papers on International Investment No. 2004/4 (2004) at 2-4, online: OECD <http://www.oecd.org/dataoecd/22154/33776546.pdf>.

$15 \quad$ Van Harten, supra note 7 at 81-82. 


\section{B. InVESTMENT ARBitration}

The concept of protection for investments is most prominent in the dispute resolution mechanism provided for in investment treaties. Introduced in bilateral investment treaties in the 1960s, the process of investment arbitration allows foreign investors to directly submit a claim against a foreign government. Investment arbitration is both a departure from the traditional methods of resolving foreign investment disputes, which relied predominantly on diplomatic channels, ${ }^{16}$ and from international adjudication in any other branch of public international law. ${ }^{17}$

Investment arbitration provides a forum, similar to the mechanism found in international commercial arbitration, for the resolution of foreign investment disputes. The process begins with the aggrieved foreign investor filing notice of its claim, typically to the International Centre for the Settlement of Investment Disputes (ICSID) or under the rules of the United Nations Commission on International Trade Law (UNCITRAL).$^{18}$ Following a period of negotiations and consultation between the investor and state, if the dispute still remains unsettled, the parties will select arbitrators to adjudicate their dispute. ${ }^{19}$ After both written submissions and an oral hearing, the arbitrators issue an award. ${ }^{20}$ If the arbitrators find in favour of the investor, it will order damages against the state, which can exceed hundreds of millions of dollars. ${ }^{21}$ The arbitral award may then be subject to limited review, mainly on procedural grounds, either in another arbitral forum or in a national court. ${ }^{22}$

16 Foreign investment disputes were traditionally resolved through the use of force ("gunboat diplomacy”) and later through state-to-state diplomatic channels, with the home state of the investor taking up the investor's cause: see Ray C. Jones, "NAFTA Chapter 11 Investor-to-State Dispute Resolution: A Shield to Be Embraced or a Sword to Be Feared?” [2002] B.Y.U.L. Rev. 527 at 529; Susan D. Franck, “The Legitimacy Crisis in Investment Treaty Arbitration: Privatizing Public International Law through Inconsistent Decisions” (2005) 73 Fordham L. Rev. 1521 at 1537.

17 Some human rights tribunals also allow individuals to initiate actions against governments but without damages: see Van Harten, supra note 7 at 103-104.

18 Convention on the Settlement of Investment Disputes between States and Nationals of Other States, 18 March 1965, 575 U.N.T.S. 159, art. 35 [ICSID Convention]; Rules of Arbitration of the International Chamber of Commerce, (1997) 22 Y.B. Comm. Arb. 347, art. 4 [ICC Rules]; UNCITRAL Arbitration Rules, UN GAOR, 31st Sess., Supp. No. 17, UN Doc. A/31/17 (1976), art. 3 [UNCITRAL Rules].

19 The arbitral tribunal is typically composed of three arbitrators, two of whom are chosen by each of the parties and the third, or chair, who is selected either by the two chosen arbitrators or the arbitral institution: see ICSID Convention, ibid., art. 37; ICC Rules, ibid., arts. 8-9; UNCITRAL Rules, ibid., arts. 5-8.

20 International Centre for Settlement of Investment Disputes, Rules of Procedure for Arbitration Proceedings, (2006) 31 Y.B. Comm. Arb. 388, r. 29 [Arbitration Rules]. See also ICSID Convention, ibid., arts. 48-49; UNCITRAL Rules, ibid., arts. 31-41; ICC Rules, ibid., art. 25.

$21 \quad$ For example, in CMS Gas Transmission v. Argentine Republic (2005), 44 I.L.M. 1205 (International Centre for the Settlement of Investment Disputes), the award was for US\$133.2 million, in CME Czech Republic B.V. v. Czech Republic (2003) (UNCITRAL), online: Investment Treaty Arbitration $<$ http://ita.law.uvic.ca/documents/CME-2003-Final_001.pdf>, the award was for US\$269 million, and in Saluka Investments BV v. Czech Republic (2006) (UNCITRAL), online: Permanent Court of Arbitration <http://www.pca-cpa.org/upload/files/SAL-CZ\%20Partial\%20Award\%20170306.pdf>, the award was for $\$ 236$ million.

22 See e.g. ICSID Convention, supra note 18, art. 52(1). For an overview of review of investment arbitral awards in national courts, see generally Barnali Choudhury, "Determining the Appropriate Level of Deference for Domestic Court Reviews of Investor-State Arbitral Awards” (2007) 32 Queen’s L.J. 602. 
For the most part, the investment arbitration process parallels the international commercial arbitration process, which mediates disputes between private contracting parties. ${ }^{23}$ Both the procedure of investment arbitration and the limited review of final arbitral awards are found in international commercial arbitration. ${ }^{24}$ Similarly, because the private nature of international commercial arbitration emphasizes confidentiality and secrecy, ${ }^{25}$ investment arbitration also has a tendency to embody these characteristics. As a result, investment arbitration typically does not provide public access to pleadings, oral hearings, or final awards. ${ }^{26}$ Public participation in investment arbitration is also limited as most hearings are closed and amicus involvement is only rarely permitted. ${ }^{27}$

Investment arbitration also borrows from the judiciary model found in international commercial arbitration. ${ }^{28}$ Because international commercial arbitration is designed to resolve disputes arising from a contractual relationship in which either party can initiate a claim against the other, arbitrators to these disputes are appointed on a case by case basis. ${ }^{29}$ Therefore, arbitrators in international commercial arbitration, and consequently also in investment arbitration, do not have tenure or financial security. Instead, they must rely on arbitral institutions and the parties themselves for reappointment. ${ }^{30}$ They are also not prohibited from acting as both arbitrator and advocate in different cases. ${ }^{31}$ Arbitrators thus have a strong interest in ensuring the continued viability of investment arbitration, which is supported by their often broad interpretations of investment treaty obligations. ${ }^{32}$

Nathalie Bernasconi-Osterwalder, "Democratizing International Dispute Settlement: The Case of Trade and Investment Disputes” (Paper presented to the 6th International Conference of New or Restored Democracies, Doha, Qatar, 29 October - 1 November 2006) at 4, online: Center for International Environmental Law <http://www.ciel.org/Publications/ICNRD6_300ct06.pdf>. Franck, supra note 16 at 1544, 1546.

25 Cindy G. Buys, “The Tensions between Confidentiality and Transparency in International Arbitration” (2003) 14 Am. Rev. Int'l Arb. 121 at 123.

26 Craig Forcese, "Does the Sky Fall?: NAFTA Chapter 11 Dispute Settlement and Democratic Accountability” (2006) 14 Michigan State Journal of International Law 315 at 325; Luke Eric Peterson \& Kevin R. Gray, International Human Rights in Bilateral Investment Treaties and in Investment Treaty Arbitration (Winnipeg: International Institute for Sustainable Development, 2005) at 10.

$27 \quad$ Amicus involvement has been permitted in selected cases, including Aguas del Tunari S.A. v. Republic of Bolivia (2005), 20 ICSID Rev. 450 (ICSID); Biwater Gauff (Tanzania) Ltd. v. United Republic of Tanzania (2007), 22 ICSID Rev. 217 (ICSID); Methanex Corporation v. United States of America, Decision of the Tribunal on Petitions from Third Persons to Intervene as “Amici Curiae” (2001), online: U.S. Department of State <http://www.state.gov/documents/organization/6039.pdf >; United Parcel Service of America Inc. v. Government of Canada, Decision of the Tribunal on Petitions for Intervention and Participation as Amici Curiae (2001), online: U.S. Department of State <http://www. state.gov/documents/ organization/6033.pdf>.

28 Alan Scott Rau, "Integrity in Private Judging” (1997) 38 S. Tex. L. Rev. 485 at 523-24.

$29 \quad$ Ibid.; Van Harten, supra note 7 at 168-69.

30 Rau, ibid. at 521-22; Andreas F. Lowenfeld, "The Party-Appointed Arbitrator in International Controversies: Some Reflections” (1995) 30 Tex. Int'l L.J. 59 at 65.

31 Aaron Cosbey et al., Investment and Sustainable Development: A Guide to the Use and Potential of International Investment Agreements (Winnipeg: International Institute for Sustainable Development, 2004) at 6; Van Harten, supra note 7 at 172.

32 For example the United Nations High Commissioner for Human Rights observes that investment arbitral tribunals are "interpreting expropriation provisions broadly in ways that could threaten ... human rights": Commission on Human Rights, Human Rights, Trade and Investment: Report of the High Commissioner for Human Rights, 55th Sess., UN Doc. E/CN.4/Sub.2/2003/9 (2003) at 3-4. Jeffery Atik also argues that arbitral tribunals have adopted "unexpectedly expansive interpretations" and "some fairly aggressive readings" to the provisions of the NAFTA: see Jeffery Atik, "Legitimacy, Transparency and NGO Participation in the NAFTA Chapter 11 Process" in Todd Weiler, ed., NAFTA Investment Law 
Interestingly, the parallels between international commercial arbitration and investment arbitration end when it comes to consenting to the process. International commercial arbitration requires both parties' consent prior to its use, while the investment arbitration process can be initiated solely at the investor's request. This is because investment treaties contain states' general consent for the use of arbitration to all future investment disputes. ${ }^{33}$ As the consent is provided ex ante, the opportunity to arbitrate is extended to a wide variety of potential claimants whose identity is unknown at the time consent is given, and for a broad range of potential disputes, the nature of which is also unknown at the time of consent. ${ }^{34}$ Thus, whereas a state party to an international commercial arbitration contractually consents with a known individual or business to submit their dispute to arbitration, state parties to investment arbitration are notified with whom they will be resolving their dispute only after the investor has initiated his or her claim.

\section{HUMAN RIgHTS IMPLICATIONS OF INVESTMENT ARBITRATIONS}

Investment treaties are premised on a reciprocal relationship: foreign investors establish investments that create more favourable economic conditions in the host state in exchange for the host state's protection of the investment. However, in liberalizing investments states have gradually begun to realize that state objectives might be at odds with the objectives of investors. Whereas states use investment to improve national development, investors are primarily interested in enhancing their own competitiveness and market share. ${ }^{35}$

The contrasting objectives of states and investors in relation to investment liberalization are most evident in investment disputes that touch upon non-commercial issues. The lack of an alternate mechanism to resolve the non-commercial aspects of an investment dispute has led to the scope of investment arbitration slowly expanding into the adjudication of noninvestment issues. ${ }^{36}$ Yet, as investment arbitration views investment disputes mainly through a commercial lens, commercial considerations tend to be prioritized over non-investment issues.

For example, many recent investment arbitrations have involved human rights issues, ${ }^{37}$ which do not form part of the traditional scope of investment treaties or investment arbitrations. In fact, investment treaties are curiously silent on the issue of human rights. The treaties neither reference the contracting parties’ international human rights obligations nor limit investor rights in accordance with the protection of human rights. Substantive

and Arbitration: Past Issues, Current Practice, Future Prospects (New York: Transnational Publishers, 2004) 135 at 147.

Jan Paulsson, “Arbitration without Privity” (1995) 10 ICSID Rev. 232 at 232-233; Alan Redfern \& Martin Hunter, Law and Practice of International Commercial Arbitration, 3d ed. (London: Sweet \& Maxwell, 1999) at 21-22.

$34 \quad$ Paulsson, ibid. at 233; Van Harten, supra note 7 at 63.

35 Commission on Human Rights, supra note 32 at 17.

$36 \quad$ Ibid. at 29.

37 Human rights refer to those rights found in the Universal Declaration of Human Rights, GA Res. 217 (III), UN GAOR, 3d Sess., Supp. No. 13, UN Doc. A/RES/217(III) (1948) 71, the International Covenant on Political and Civil Rights, 16 December 1966, 999 U.N.T.S. 171; International Covenant on Economic, Social and Cultural Rights, 16 December 1966, 993 U.N.T.S. 3. 
provisions detailing human rights obligations are also absent from investment treaties. ${ }^{38}$ As a result, investment arbitrations have tended to discount or negate human rights issues entirely.

Obligations in investment treaties also have the ability to impair human rights, sometimes even before proceeding to arbitration. ${ }^{39}$ These provisions may also exacerbate any human rights wrongs if interpreted broadly during arbitration.

\section{A. INVESTMENT ARBITRATIONS IMPLICATING HuMAN RigHTS ISSUES}

The intersection of investment arbitration and human rights is probably best evidenced in two pending arbitrations. In both disputes, foreign investments have been affected by state regulations that implicate core societal values and the protection of historically disadvantaged peoples.

In Piero Foresti v. South Africa, ${ }^{40}$ Italian investors challenged South African laws aimed at redressing the historical, social, and economic inequalities faced by the Black community in South Africa during the apartheid regime. The dispute arose from the 2003 Black Economic Empowerment (BEE) policy, ${ }^{41}$ which allowed the government to condition the issuance of state licenses for mining rights on companies' compliance with social, labour, and development objectives. Pursuant to the BEE policy, the government required mining companies to hire both Black or historically disadvantaged South African (HDSA) managers and sell 26 percent of shareholdings to Blacks or HDSAs. ${ }^{42}$

The Italian investors in a mining company claimed that the BEE's mining regime violated South Africa's investment treaty obligations. In particular, they alleged that the forced divesture of their shareholdings to Blacks and HDSAs was both an expropriation and a denial of fair and equitable treatment. They also alleged national treatment violations, arguing that they were discriminated against by being treated less favourably than Blacks and HDSAs. ${ }^{43}$

In a second case, the United States government faced an investment arbitration from a Canadian mining company due to efforts to preserve Native American sacred lands from holes created by open-pit mining operations. ${ }^{44}$ Since 1987 , mining company Glamis Gold has attempted to establish an open-pit gold mine in the Imperial Valley of California. Glamis’

38 Ryan Suda, “The Effect of Bilateral Investment Treaties on Human Rights Enforcement and Realization” in Olivier De Schutter, ed., Transnational Corporations and Human Rights (Oxford: Hart, 2006) 73 at 90; Peterson \& Gray, supra note 26 at 8-9.

39 See Part II.B, below for more on this topic.

40 Case No. ARB/(AF)/07/1 (ICSID) [Piero Foresti]. Pursuant to party agreement, proceedings were suspended on 28 May 2009.

41 Broad-Based Black Economic Empowerment Act 2003, No. 53 of 2003 [BEE]. For an overview of the $B E E$ see South Africa, Department of Trade and Industry, South Africa's Economic Transformation: A Strategy for Broad-Based Black Economic Empowerment, online: Department of Trade and Industry $<$ http://www.thedti.gov.za/bee/complete.pdf $>$.

42 Ibid.

43 Ibid.

44 Glamis Gold Ltd. v. United States of America [Glamis]. For a full list of the pleadings associated with this case see online: U.S. State Department <http://www.state.gov/s/l/c10986.htm>. 
initial request for a permit to operate the mine was denied due to environmental concerns and apprehension about the adverse impact the mine could have on a local Native American tribe's religious sites. When a change in federal government later reversed the denial of Glamis' permit, the California government passed emergency legislation requiring the backfilling and re-contouring of new open-pit metallic mines in protected areas of the California desert near sacred indigenous lands. ${ }^{45}$ Glamis argued that the California regulations destroyed the value of its investment. In 2003, Glamis initiated an investment arbitration against the U.S. government, claiming that the California regulations were tantamount to expropriation and a denial of fair and equitable treatment. ${ }^{46}$

In addition to Piero Foresti and Glamis, investment arbitrations have also implicated other human rights including the right to water, the right to health, and rights related to culture. ${ }^{47}$

\section{THE RIGHT TO WATER}

The right to water is found in several international human rights treaties, including the International Covenant on Economic, Social and Cultural Rights, ${ }^{48}$ the Convention on the Rights of the Child, ${ }^{49}$ and the Convention on the Elimination of all forms of Discrimination Against Women. ${ }^{50}$ Pursuant to the right to water, everyone is entitled to quality water that is both available and accessible. ${ }^{51}$ Water providers are accordingly required to provide a system of water supply and management that provides "equality of opportunity for people to enjoy the right to water." 52

In several South American and African states, water services have been privatized and are being provided by foreign investors. This private provision of water services has often triggered human rights concerns when the quality or affordability of the water is compromised. ${ }^{53}$ For example, in Bolivia, the investor increased water tariffs by 400 percent

Glamis Gold Ltd. v. United States of America, Counter Memorial of Respondent United States of America, (19 September 2006) at 37-48, online: U.S. State Department <http://www.state.gov/ documents/organization/73686.pdf>. online: U.S. State Department <http://www.state.gov/documents/organization/27320.pdf>.

For an overview of human rights issues in investment arbitrations see Peterson \& Gray, supra note 26; Howard Mann, International Investment Agreements, Business and Human Rights: Key Issues and Opportunities (Winnipeg: International Institute for Sustainable Development, 2008).

Supra note 37.

20 November 1989, 1577 U.N.T.S. 3 (entered into force 2 September 1990).

18 December 1979, 1249 U.N.T.S. 13 (entered into force 3 September 1981).

Committee on Economic, Social and Cultural Rights, Substantive Issues Arising in the Implementation of the International Covenant on Economic, Social and Cultural Rights, General Comment No. 15 (2002): The Right to Water (arts. 11 and 12 of the International Covenant on Economic, Social and Cultural Rights), UN ESCOR, 29th Sess., UN Doc. E/C.12/2002/11 (2003) at 5-6.

Ibid. at 4.

For example, investment arbitrations involving water and/or sewage services include: Compañía de Aguas del Aconquija S.A. and Vivendi Universal v. Argentine Republic (2007), Case No. ARB/97/3 (ICSID), online: Investment Treaty Arbitration <http://ita.law.uvic.ca/documents/VivendiAwardEnglish. pdf>; Suez, Sociedad General de Aguas de Barcelona S.A. and Interagua Servicios Integrales de Agua S.A. v. Argentine Republic, Case No. ARB/03/17 (ICSID); Suez, Sociedad General de Aguas de Barcelona S.A. and Vivendi Universal S.A. v. Argentine Republic, Case No. ARB/03/19(ICSID); Azurix Corp. v. Argentine Republic, Case No. ARB/03/30 (ICSID); SAUR International v. Argentine Republic, Case No. ARB/04/4 (ICSID); Urbaser S.A. and Consorcio de Aguas Bilbao Biskaia, Bilbao Biskaia Ur 
and began to charge users for water from their own private wells; ${ }^{54}$ problems with water quality and water pressure arose after U.S. investor Azurix began the provision of water services in Argentina; ${ }^{55}$ and French investor Vivendi increased tariffs by 110 percent and provided black, undrinkable water when it began providing water services in Argentina. ${ }^{56}$ These apparent compromises on the right to water, however, have never formed part of the Tribunal's reasoning in the investment arbitrations that resulted from these disputes. As one Tribunal noted, state measures to correct the problems flowing from the foreign investors' provision of water services, although exercises of its public authority for the protection of public health, ${ }^{57}$ could compromise state obligations under an investment treaty to proactively encourage and protect the investment. ${ }^{58}$

\section{The Right TO HEALth}

The right to health, recognized in several international agreements, dictates the right of everyone to the enjoyment of the highest attainable standard of health. ${ }^{59}$ In addition to timely and appropriate health care, the right to health also encompasses the underlying determinants of health such as access to safe and potable water and adequate sanitation, an adequate supply of safe food, nutrition, and housing, and healthy occupational and environmental conditions. $^{60}$

As with the right to water, the right to health has also been implicated in several investment arbitrations with mixed results. In Methanex Corp. v. United States of America, for example, a Canadian investor argued that California's ban on methyl tert-butyl ether (MTBE), a gasoline additive, violated the U.S.'s obligations under the NAFTA. ${ }^{61}$ California had instituted the ban due to concerns arising from the leakage of MTBE into its water, both

Partzuergoa v. Argentine Republic, Case No. ARB/07/26 (ICSID); Impregilo S.p.A. v. Argentine Republic, Case No. ARB/07/17 (ICSID); Aguas Cordobesas S.A., Suez, and Sociedad General de Aguas de Barcelona S.A. v. Argentine Republic, Case No. ARB/03/18 (ICSID) (Settlement reached); Biwater Gauff (Tanzania) Limited v. United Republic of Tanzania (2008), Award (ICSID); Azurix Corp. v. Argentine Republic (2006), Case No. ARB/01/12 (ICSID) (annulment proceeding pending) [Azurix]. Maria McFarland Sánchez-Moreno \& Tracy Higgins, "No Recourse: Transnational Corporations and the Protection of Economic, Social, and Cultural Rights in Bolivia” (2004) 27 Fordham Int’l L.J. 1663 at $1766-67$.

Azurix Corp. v. Argentine Republic (2006) at paras. 126-44 (ICSID), online: ICSID <http://icsid.world bank.org> (providing a synopsis of the circumstances at the time of the dispute and the Tribunal's own view of the circumstances).

Compañía de Aguas del Aconquija and Vivendi Universal v. Argentine Republic, supra note 53 at paras. 4.9.1, 4.10.3.

Ibid. at para. 6.5.1.

Ibid. at 7.5.21.

International Covenant on Economic, Social and Cultural Rights, supra note 37, art. 12(1). See also, Universal Declaration of Human Rights, supra note 37, art. 25(1); International Convention on the Elimination of All Forms of Racial Discrimination, 7 March 1966, 660 U.N.T.S. 195 (entered into force 4 January 1969); Convention on the Elimination of All Forms of Discrimination against Women, supra note 50, arts. 11(1)(f); Convention on the Rights of the Child, supra note 49, art. 24.

Committee on Economic, Social and Cultural Rights, Substantive Issues Arising in the Implementation of the International Covenant on Economic, Social and Cultural Rights, General Comment No. 14 (2000): The Right to the Highest Attainable Standard of Health (article 12 of the International Covenant on Economic, Social and Cultural Rights), 22d Sess., UN Doc. E/C.12/2000/41 (2000) at para. 4.

Final Award of the Tribunal on Jurisdiction and Merits (3 August 2005), online: U.S. Department of State <http://www.state.gov/documents/organization/51052.pdf $>$ [Methanex]. 
contaminating its water supply and posing a health risk to California residents. The Tribunal found merit in California's health concerns and dismissed the complaint outright after finding that the regulations were non-discriminatory in nature and enacted with due process. ${ }^{62}$

However, tribunals have not adopted the Methanex rationale in other disputes involving health concerns. For example, in S.D. Myers Inc. v. Government of Canada, ${ }^{63}$ the Canadian government banned the transboundary export of $\mathrm{PCB}^{64}$ waste to ensure that the waste was "managed in an environmentally sound manner ... and to prevent any possible significant danger ... to human life or health." ${ }^{\text {" }}$ American investor S.D. Myers challenged the ban in an investment arbitration. Although the Tribunal took note of the health and environmental impacts of the transboundary movement of hazardous waste in its decision, it found that Canada should have used a measure less restrictive on trade to fulfill its objectives. ${ }^{66}$ In the end, the Tribunal found in favour of the investor. ${ }^{67}$

Similarly, in Tecnicas Medioambientales Tecmed S.A. v. The United Mexican States, which involved a dispute involving the renewal of a permit for the operation of a hazardous waste landfill site, the Tribunal's reasoning did not take into account the health and environmental concerns that had been raised in connection with the operation of the site. ${ }^{68}$ Instead, in finding in favour of the investor, the Tribunal held that regulatory administrative actions are not "per se excluded from the scope of the [investment treaty], even if they are beneficial to society as a whole." 69

\section{Rights RELATED TO CULTURE}

In addition to the protection of civil and political rights, human rights can also encompass the protection of economic, social, and cultural rights. The International Covenant on the Protection of Economic, Social and Cultural Rights notes that "the ideal of free human beings enjoying freedom from fear and want can only be achieved if conditions are created whereby everyone may enjoy his economic, social and cultural rights." ${ }^{70}$ In the area of cultural rights states are thus obliged to conserve, develop, and diffuse culture. ${ }^{71}$

Investment arbitrations have also implicated rights related to culture. Thus, in ParkeringsCompagniet AS $v$. Republic of Lithuania,$^{72}$ the investor applied for a tender to establish car

62

Ibid.

Partial Award (13 November 2000), online: Foreign Affairs and International Trade <http://www. international.gc.ca/trade-agreements-accords-commerciaux/assets/pdfs/myersvcanadapartial award_final_13-11-00.pdf> [S.D. Myers].

PCB refers to polychlorinated biphenyl (PCB) chemicals.

S.D. Myers, supra note 63 at para. 123.

Ibid. at para. 215.

S.D. Myers v. Canada, Second Partial Award (21 October 2002), online: <http://www.international. gc.ca/trade-agreements-accords-commerciaux/assets/pdfs/MyersPA.pdf $>$. The Tribunal's finding in favour of the investor was also justified by its finding that Canada's ban had been motivated by a protectionist intent: see S.D. Myers, ibid. at paras. 162, 254-56.

(2003), 43 I.L.M. 133 (ICSID) [Tecmed].

Ibid. at para. 121.

Supra note 37, Preamble.

Ibid., art. 15(2).

(2007) (ICSID), online: ICSID <http://icsid.worldbank.org> [Parkerings]. 
parks in Vilnius, Lithuania, an United Nations Educational, Scientific and Cultural Organization (UNESCO) World Heritage site, which it was later awarded. During the course of planning and designing the car parks, the City of Vilnius stopped the investor's plan due to cultural concerns. Specifically, concerns were expressed about the encroachment of the car parks onto the city's historical center, which officials thought could change the old town or destroy large areas of unexplored cultural layer. ${ }^{73}$

In an investment arbitration, the investor argued that because the City had later awarded the car park contract to another operator, Lithuania had breached its investment treaty obligations. However, the Tribunal disagreed. Instead, it found that Lithuania's distinction between an operator that would establish a car park that would not impede on Vilnius' culturally sensitive areas and the investor, whose project designs encroached upon cultural areas, was a legitimate distinction that did not give rise to a breach of Lithuania's investment treaty obligations. ${ }^{74}$

In contrast, in Southern Pacific Properties (Middle East) Limited v. Arab Republic of Egypt, cultural rights were not accorded the same level of consideration. ${ }^{75}$ SPP involved a Hong Kong investor that formed a joint venture to develop tourist complexes near the pyramids in Cairo, Egypt. The Egyptian government later decreed the lands around the pyramids to be public property, confirming the presence of antiquities on the land. ${ }^{76}$ Government approval for the development of the tourist complexes was also withdrawn in response to the antiquity decree and the contract with the investor to develop the land cancelled. ${ }^{77}$ Thereafter, the investor initiated arbitral proceedings. ${ }^{78}$

The Tribunal held that the government of Egypt had the sovereign right to "cancel a tourist development project situated on its own territory for the purpose of protecting antiquities" in the area. ${ }^{79}$ However, it found that the right to cancel the project triggered a duty of compensation and the Tribunal, accordingly, ordered damages in excess of US\$27 million in favour of the investor. ${ }^{80}$

\section{B. INVESTMENT TREATY OBLIGATIONS THAT LIMIT THE Protection of Human Rights}

As the Piero Foresti, Glamis, and other disputes implicating human rights demonstrate, investment arbitrations implicating human rights issues tend to focus on two particular investment treaty obligations: expropriation and fair and equitable treatment. Despite the numerous obligations found in investment treaties, these two obligations have the greatest

Ibid. at paras. 142, 144-45, 147.

Ibid. at paras. 392, 396. More specifically, recognition of this distinction allowed the Tribunal to conclude that Lithuania had not breached its MFN obligations under the investment treaty.

(1993), 8 ICSID Rev. 328 [SPP].

Ibid. at para. 63.

Ibid. at para. 64.

Ibid. at para. 67.

Ibid. at para. 158.

Ibid. at paras. 159, 257. 
potential to place limits upon state action for the protection and promotion of human rights while favouring commercial interests of foreign investors. ${ }^{81}$

In particular, the strength of these obligations has caused them to be likened to an economic bill of rights or even a form of human rights protection exclusively for investors. ${ }^{82}$ Expropriation and fair and equitable treatment obligations also operate akin to constitutional rights in that they are assigned the highest degree of protection and can effectively limit the authority of governments. ${ }^{83}$ Nevertheless, the rights arising from these obligations cannot be equated to the basic rights and liberties reflected in human rights. ${ }^{84}$ Human rights, after all, protect the inherent dignity of all persons while the rights granted to investors and investments by these obligations are given merely "to promote a specific approach to economic policy." 85

The strength of expropriation and fair and equitable treatment obligations is also reflected in their ability to create a "chilling effect" on government regulatory capacity. ${ }^{86}$ States, fearing that a regulation could be challenged by a foreign investor and then subject to a multi-million dollar damage award under these obligations, may be discouraged from enacting regulations that enforce human rights obligations against foreign investors. ${ }^{87}$ In addition, because these obligations are drafted in broad terms and the lack of a precedent system in investment arbitration prevents a harmonious interpretation of these obligations, the uncertainty associated with the scope of the obligations may also negatively impact on state initiatives to regulate human rights.

\section{EXPROPRIATION}

One of the most common allegations in investment arbitrations is that the state's interference resulted in an expropriation. In addition to direct expropriations, ${ }^{88}$ expropriations can be indirect, wherein state interferences in the use or enjoyment of an investment deprive

81 Commission on Human Rights, supra note 32 at 21.

82 Susan D. Franck, “Empirically Evaluating Claims About Investment Treaty Arbitration” (2007) 86 N.C.L. Rev. 1 at 9; Robert Wai, “Countering, Branding, Dealing: Using Economic and Social Rights in and around the International Trade Regime” (2003) 14 E.J.I.L. 35 at 42.

83 David Schneiderman, Constitutionalizing Economic Globalization: Investment Rules and Democracy’s Promise (Cambridge: Cambridge University Press, 2008) at 4.

84 Philip Alston, "Resisting the Merger and Acquisition of Human Rights by Trade Law: A Reply to Petersmann” (2002) 13 E.J.I.L. 815.

$85 \quad$ Ibid. at 826.

$86 \quad$ Ibid. See also United Nations Conference on Trade and Development, World Investment Report 2003: FDI Policies for Development: National and International Perspectives (New York: United Nations, 2003) at 111 [Investment Report 2003].

87 Thomas W. Wälde, “Investment Arbitration Under The Energy Charter Treaty: From Dispute Settlement to Treaty Implementation” (Paper presented to the Conference on Energy-Arbitration, Gulf Arbitration Centre, October 1998) at 6, online: Centre for Energy, Petroleum and Mineral Law and Policy $<$ http://www.dundee.ac.uk/cepmlp/journal/html/Vol/article1-10.pdf>; Schneiderman, supra note 83 at 71; Wai, supra note 82 at 68 ("There is evidence that debate in Canada on some matters of social policy now operates in the shadow of Chapter 11").

$88 \quad$ OECD, supra note 14 at 3; Amoco International Finance Corp. v. Iran, (1987) 15 Iran-U.S. Claims Tribunal Reports 189 at 220. 
the investor of all benefits of the property except its legal title. ${ }^{89}$ Both direct and indirect expropriations are considered compensable. ${ }^{90}$

Customary international law also recognizes a third form of property interference. Thus, state regulations, enacted as a lawful exercise of governmental powers, may affect foreign investments. ${ }^{91}$ However, as these state regulations are enacted within the "police powers" of the state, these types of interferences are not considered to amount to expropriations and are accordingly not compensable. ${ }^{92}$

Nevertheless, the line between indirect expropriations and interferences arising from a state's police powers is not clear. Accordingly, the extent to which a state can affect an investment by way of a bona fide regulation to serve a legitimate public purpose without effectuating a taking and triggering compensation is uncertain. ${ }^{93}$

The unresolved nature of this issue has the potential to curtail states' human rights regulatory initiatives. ${ }^{94}$ For example, in Ethyl Corp. v. Government of Canada, the Canadian government withdrew the legislation banning methylcyclopentadienyl manganese tricarbonyl (MMT) at least partially in response to a claim for expropriation in an investment arbitration even though the legislation was designed to protect public health. ${ }^{95}$ Similarly, in Indonesia, after the government banned open-pit mining in protected forests, the threat of expropriation claims from affected mining companies caused the government to repeal the ban. ${ }^{96}$

The lack of clear understanding of the distinction between indirect expropriations and regulations within the state's police powers can also negatively affect the protection of human rights. Thus, in Compañía del Desarrollo de Santa Elena S.A. v. The Republic of Costa Rica, the Tribunal held that the environmental purpose for the taking of the property did not "alter the legal character of the taking for which adequate compensation must be

Cosbey et al., supra note 31 at 13; Rudolf Dolzer, "Indirect Expropriation of Alien Property” (1986) 1 ISCID Rev. 41; OECD, ibid. at 3-4; Investment Report 2003, supra note 86 at 110-11.

Dolzer \& Stevens, supra note 3 at 97; OECD, ibid. at 2-4.

Ian Brownlie, Principles of Public International Law, 6th ed. (Oxford: Oxford University Press, 2003) at 509. See also Sedco Inc. v. National Iranian Oil Co. (1985) 9 Iran-U.S. Claims Tribunal Reports 248 at 275 (it is "an accepted principle of international law that a State is not liable for economic injury which is a consequence of bona fide 'regulation' within the accepted police power of states").

Brownlie, ibid.; Allen S. Weiner, "Indirect Expropriations: The Need for a Taxonomy of 'Legitimate' Regulatory Purposes” (2003) 5 International Law Forum 166 at 168.

OECD, supra note 14 at 2.

Suda, supra note 38 at 93-94.

(1999), 24 Y.B. Comm. Arb. 211 [Ethyl]. For a complete listing of the pleadings associated with this arbitration, see online: Foreign Affairs and International Trade Canada <http://www.international.gc. ca/trade-agreements-accords-commerciaux/disp-diff/ethyl_archive.aspx?lang=en $>$. See also Michelle Sforza \& Mark Vallianatos, "NAFTA \& Environmental Laws: Ethyl Corp. v. Government of Canada" Global Policy Forum (April 1997), online: Global Policy Forum <http://www.globalpolicy.org/socecon/ envronmt/ethyl.htm>; Private Rights, Public Problems: A Guide to NAFTA's Controversial Chapter on Investor Rights (Winnipeg: International Institute for Sustainable Development, 2001) at 73. Canada may have also settled the claim because its legislation was deemed inconsistent with the federal government's obligations under its Agreement on Internal Trade: see Alan C. Swan, "Ethyl Corporation v. Canada, Award on Jurisdiction (Under NAFTA/UNCITRAL),” Case Comment, (2000) 94 A.J.I.L. 159 at 160 .

Stuart G. Gross, “Inordinate Chill: BITs, Non-NAFTA MITs, and Host-State Regulatory Freedom An Indonesian Case Study” (2003) 24 Mich. J. Int’l L. 893 at 894-95. 
paid," negating the state's police powers entirely. ${ }^{97}$ Tribunals have also held that because the foreign investor is unable to participate in the democratic processes that allowed the adoption of the state regulation affecting the investment, it may be reasonable for "nationals to bear a greater burden in the public interest than non-nationals." ${ }^{\text {"98 }}$

Only the Methanex Tribunal has recognized the state's police power, finding that a regulation enacted for a public purpose, which is non-discriminatory and enacted with due process, can affect a foreign investment without constituting an expropriation or triggering compensation. ${ }^{99}$ Under this rationale, state measures to protect and promote human rights cannot be characterized as compensable expropriations unless the regulation is discriminatory in nature or suffers from due process shortcomings. However, because of the lack of precedent in investment arbitration, the rationale in Methanex is not binding and the difference between indirect expropriations and regulations within police powers remains unsettled.

\section{FAIR AND EQUITABLE TREATMENT}

Another provision commonly invoked by investors is the duty to provide "fair and equitable treatment." ${ }^{00}$ The broad and ambiguous nature of this obligation has been described as "so general a provision [that it] is likely to be almost sufficient to cover all conceivable cases." ${ }^{101}$ Initially interpreted to implicate only egregious state conduct, ${ }^{102}$ the fair and equitable standard has now evolved to engage a range of state conduct including arbitrary, unjust, or discriminatory conduct. ${ }^{103}$ Fair and equitable treatment may also require state conduct to be transparent, in good faith, and considerate of an investor's legitimate expectations. ${ }^{104}$ Still, the precise scope of the duty of fair and equitable treatment continues to remain uncertain as new tribunals interpret its meaning.

Recently, however, a prominent commentator has observed that there may be an emerging consensus on specific facets of fair and equitable treatment. ${ }^{105}$ Specifically, Professor Vaughan Lowe argues that tribunals should consider the concepts of transparency and legitimate expectations as part of their analysis under the standard of fair and equitable

(2000), 15 ICSID Rev. 169 at para. 71.

Azurix, supra note 53 at para. 311; see also Tecmed, supra note 68 at paras. 121-22.

Methanex, supra note 61 at Part IV, c. D, para. 7.

Dolzer \& Stevens, supra note 3 at 58-60; Sornarajah, supra note 3 at 235-36.

F.A. Mann, "British Treaties for the Promotion and Protection of Investments" (1981) 52 Brit. Y.B. Int'l L. 241, reprinted in S.D. Myers, supra note 63 at para. 265.

Neer v. United Mexican States (1926), 4 R.I.A.A. 60 (Mexico-United States General Claims Commission).

See generally Vaughan Lowe, “Changing Dimensions of International Investment Law” Oxford Legal Studies Research Paper Series 4/2007 (Marcy 2007) at 84-96, online: Social Science Research Network $<$ http://papers.ssrn.com/sol3/papers.cfm?abstract_id=970727>; Barnali Choudhury, "Evolution or Devolution?: Defining Fair and Equitable Treatment in International Investment Law” (2005) 6 Journal of World Investment \& Trade 297; Richard H. Kreindler, "Fair and Equitable Treatment - A Comparative International Law Approach" (Paper presented to the "International Investment Law at a Crossroads” Conference, Harvard Law School, 3 March 2006), (2006) 3:3 Transnational Dispute Management 1 at 7-9.

Lowe, ibid. at 97-98; Choudhury, ibid. at 302-05, 308-11; Kreindler, ibid. at 9.

Lowe, ibid. at 98. 
treatment. ${ }^{106}$ Yet, the routine incorporation of these concepts into the fair and equitable standard may have a significant impact on states’ ability to regulate human rights issues.

The Tecmed Tribunal was one of the first to incorporate the concepts of transparency and legitimate expectations into the standard of fair and equitable treatment. ${ }^{107}$ The Tribunal held that fair and equitable treatment requires states to provide investments with "treatment that does not affect the basic expectations that were taken into account by the foreign investor to make the investment." ${ }^{108}$ It also observed:

The foreign investor expects the host State to act in a consistent manner, free from ambiguity and totally transparently in its relations with the foreign investor, so that it may know beforehand any and all rules and regulations that will govern its investments, as well as the goals of the relevant policies and administrative practices or directives, to be able to plan its investment and comply with such regulations. ${ }^{109}$

However, if fair and equitable treatment is interpreted in accordance with the reasoning in Tecmed and the cases that have followed it, states' regulatory powers will be strictly constrained. Democratic states will likely not be able to provide an investor with "any and all rules and regulations" that will govern its investments. ${ }^{110}$ As the Parkerings Tribunal acknowledged, laws will evolve over time and states have to be able to react to govern new developments, ${ }^{111}$ particularly in the area of human rights. A broad interpretation of the fair and equitable treatment may, consequently, constrain this governmental function.

\section{The FAILURE OF InVESTMENT ARBITRATION TO ALIGN WITH CONCEPTS OF DEMOCRACY}

The survey of investment treaty provisions and disputes highlights the ability of investment arbitration both to constrain sovereign regulatory authority and to implicate core values of a society that human rights issues represent. The implication of issues of the public good in investment disputes thus suggests that the adjudication of these issues should be confined to a system that aligns with the framework of democracy. However, investment arbitration is a curiously undemocratic system. The treaties that create investment arbitration do not reflect democratic consent nor does the investment arbitration process itself incorporate democratic values.

Before turning to a democratic criticism of investment arbitration, it is important to define the ideas of democracy that the criticism incorporates, particularly as democracy is a highly contested concept capable of different meanings to different people. ${ }^{112}$ In general, democracy

Ibid.

Tecmed, supra note 68 at paras. 123, 154, 162, 164.

Ibid. at para. 154.

Ibid.

Suda, supra note 38 at 102.

Parkerings, supra note 72 at para. 332.

Robert Howse, The WTO System: Law, Politics and Legitimacy (London: Cameron May, 2007) at 57;

Robert F. Housman, “Democratizing International Trade Decision-Making” (1994) 27 Cornell Int'l L.J. 699 at $702-703$. 
is thought to involve the concept of "government by and for the people." 113 Democracy can also involve the citizen's right to have knowledge of and participate in decisions that will affect their interests. ${ }^{114}$ Public discourse is thus an integral element of deliberative decisionmaking in that decision-making by deliberation and rational discourse is thought to generate reasonable results accepted by all participants. ${ }^{115}$ Public policy decisions arising out of a democratic process accordingly require representative decision-making at the procedural level and a substantive requirement of informed decision-making through rational discourse. ${ }^{116}$

In addition to democratic principles, legitimacy for public policy decisions is also dependent on the rule of law. ${ }^{117}$ Under the rule of law, an independent judiciary functions to constrain majoritarian excesses in order to protect fundamental rights and liberties. ${ }^{118} \mathrm{Judicial}$ review of majoritarian political process is thus justified by the need for public policies to reflect ideals of equality or protection of minority rights. ${ }^{119}$

Accordingly, decisions arising out of investment arbitration that implicate human rights considerations must adhere to ideas of representative democracy, deliberative democracy, and the attributes of an adjudicative mechanism under the rule of law. Investment arbitration, however, fails to accord with these principles because the investment treaties that create the process do not reflect democratic consent and the process itself lacks many of these principles.

\section{A. INVESTMENT TREATIES DO NOT NECESSARILY REFLECT DEMOCRATIC CONSENT}

Under a concept of representative democracy, public consent for governmental acts is indirect; elected representatives and their delegates provide their own consent for state acts. ${ }^{120}$ The relationship between the public and elected representatives can consequently be analogized to a principal-agent relationship in which the public occupies the role of the

113 Housman, ibid. at 703; see also Nicolas N. Kittrie, "Democracy: An Institution Whose Time has Come — From Classical Greece to the Modern Pluralistic Society” (1993) 8 Am. U. J. Int'l L. \& Pol'y 375 at 379.

114 See generally Carole Pateman, Participation and Democratic Theory(Cambridge: Cambridge University Press, 1970).

115 Jürgen Habermas, Between Facts and Norms: Contributions to a Discourse Theory of Law and Democracy, trans. by William Rehg (Cambridge, Mass.: MIT Press, 1996) at 298.

116 Markus Krajewski, “Democratic Legitimacy and Constitutional Perspectives of WTO Law” (2001) 35 J. World Trade 167 at 171.

117 Ibid.

118 Paul B. Stephan, “Accountability and International Lawmaking: Rules, Rents And Legitimacy” (199697) 17 Nw. J. Int'l L. \& Bus. 681 at 684; John Hart Ely, Democracy and Distrust: A Theory of Judicial Review (Cambridge: Harvard University Press, 1980) at 41; Anupam Chander, "Globalization and Distrust” (2005) 114 Yale L.J. 1193 at 1196.

119 Chander, ibid. at 1203; Howse, supra note 112 at 58.

120 Ann Capling, "Legitimacy Begins at Home: Overcoming the Democratic Deficit in Domestic Trade Policy-Making” (Paper presented to the Centre for the Study of Globalisation and Regionalisation (CSGR) Conference, University of Warwick, 17-19 September 2007) at 3, online: CSGR <http://www2. warwick.ac.uk/fac/soc/csgr/activitiesnews/conferences/conference2007/papers/Capling.pdf>. 
principal and representatives and their delegates act as agents. ${ }^{121}$ Under this view, consent for governmental acts by elected representatives or their delegates will not reflect the consent of the public when agency costs arise or information asymmetries exist between principals and agents. ${ }^{122}$ These types of agency costs are evident in the negotiation and formulation of investment treaties.

Investment treaties, containing the investment arbitration mechanism, are generally negotiated by trade negotiators who are delegated the task by elected representatives or their delegates. However, negotiators may have different interests in concluding investment treaties than either elected representatives or the general public. For example, investment treaty negotiators may have a greater commitment to investment liberalization and economic interests over other interests. ${ }^{123}$ In addition, because investment treaty negotiation involves a process of bargaining rather than seeking out the best solution to an issue, interests will only be protected as part of a "package deal," which may result in the compromise of one interest over another. ${ }^{124}$ Moreover, as "repeat players," negotiators may also prize good working relationships with other negotiators over the protection of particular interests. ${ }^{125}$ In addition, negotiators may perceive risk and values differently from the public. ${ }^{126}$

Investment treaty negotiators are also more likely to be beholden to special interest groups than other elected representatives and their delegates. ${ }^{127}$ Although these negotiators are less likely to be subject to the capture of protectionist interest groups, the interests of multinational corporations in pursuing continued liberalization may not reflect the multitude of interests of the public. ${ }^{128}$

Information asymmetries can similarly result in agency costs between both the public and elected representatives and investment treaty negotiators. Investment treaty negotiations are typically conducted with a lack of transparency. ${ }^{129}$ The secrecy that marks investment treaty negotiations makes it difficult for outsiders to decipher the negotiator's positions taken during the negotiation, the amount of conviction behind the position held, or the bargaining

121 Cary Coglianese \& Kalypso Nicolaidis, "Securing Subsidiarity: The Institutional Design of Federalism in the United States and Europe” in Kalypso Nicolaidis \& Robert Howse, eds., The Federal Vision: Legitimacy and Levels of Governance in the United States and the European Union (Oxford: Oxford University Press, 2001) 277 at 281.

Ibid. Agency costs represent the difference in interests between principals and agents.

Andrew T. Guzman, “Trade, Labor, Legitimacy” (2003) 91 Cal. L. Rev. 885 at 888; Howse, supra note 112 at 60.

Krajewski, supra note 116 at 177; Peter K. Yu, “The International Enclosure Movement” (2007) 82 Ind. L.J. 827 at 892.

Robert O. Keohane \& Joseph S. Nye, Jr., "The Club Model of Multilateral Cooperation and the World Trade Organization: Problems of Democratic Legitimacy” (2001), online: John F. Kennedy School of Government $<$ http://www.hks.harvard.edu/visions/publication/keohane_nye.pdf $>$; Howse, supra note 112 at 60.

Howse, ibid.

Jeffery Atik, “Democratizing the WTO” (2001) 33 Geo. Wash. Int'l L. Rev. 451 at 459. See also John O. McGinnis \& Mark L. Movsesian, “The World Trade Constitution” (2000) 114 Harv. L. Rev. 511 at 515.

Keohane \& Nye, supra note 125 at 17-18.

Ibid. at 3; Howse, supra note 112 at 60. 
process that resulted in the compromises taken. ${ }^{130}$ Investment treaties are thus often presented as fait accompli. ${ }^{131}$

In addition to the lack of public knowledge of the substance of investment treaty negotiations, government officials outside the trade and investment department may also be excluded from the process of investment treaty negotiations. For example, a minister of a large Latin American country has admitted that he was unaware that his country had entered into investment treaties. ${ }^{132}$ Government officials in other departments are also typically excluded from the process, such that environmental or labour officials do not partake in formulating investment treaty policies even if there is a linkage between areas. ${ }^{133}$ Moreover, for those states in which ex post legislative approval is used, suggesting that information asymmetries in these systems are reduced, the perfunctory nature of these approvals suggests otherwise. ${ }^{134}$ In addition, for many investment treaties, even a well reasoned ex post approval may have been meaningless as the implications of these treaties on public values may not have been fully understood at the time of approval. ${ }^{135}$

Thus, with the possibility of varying interests between investment treaty negotiators and the public during the course of treaty negotiations, combined with the information asymmetries between both the public and different divisions of the government and investment treaty negotiators, the potential for agency costs is high. As a result, investment treaties likely do not reflect democratic consent.

\section{B. The Process of InVEstMent ARbitration IS DEMOCRATICALLY DEFICIENT}

Even if democratic consent was provided for the entrance into investment treaties, the investment arbitration process itself counters democratic principles. In particular, the notion of deliberative democracy is undercut by investment arbitration's severe limitations on public discourse. Limiting public access to the pleadings, hearings, and decisions of investment arbitrations has resulted in the public's general ignorance of investment arbitration and the subject matter of the disputes. ${ }^{136}$ This is particularly detrimental to the promotion of democracy, especially with the growing number of disputes involving core societal values, such as issues of human rights.

Investment arbitration also suffers from countermajoritarian criticism. Associated with most forms of adjudicative review, the countermajoritarian difficulty arises out of the inconsistency between the judicial restraint of the majority will and the majority's right to

Keohane \& Nye, ibid.; Howse, ibid.

Krajewski, supra note 116 at 176; Keohane \& Nye, ibid.

Thomas Waelde, “Current Issues in Investment Disputes: Comments” (14 February 2001), online: Centre for Energy, Petroleum and Mineral Law and Policy <http://www.dundee.ac.uk/cepmlp/journal/ $\mathrm{html} /$ forum_8.html>.

Keohane \& Nye, supra note 125 at 3.

Capling, supra note 120 at 14-15; Howse, supra note 112 at 61; Atik, supra note 127 at 459.

Howse, ibid. at 62.

See the discussion in Part I.B, above. 
have their will rule supreme in a democracy. ${ }^{137}$ More specifically, countermajoritarian criticism focuses on "whether the judiciary acting alone can interfere with popular will."138 International adjudicative mechanisms are often plagued with countermajoritarian criticisms, although several commentators have argued that these criticisms are overstated if international judicial review protects insular minorities or can be corrected with a legislative override. $^{139}$

However, investment arbitration does not protect minority interests and "correction" of its decisions is limited. As the review of investment arbitrations implicating human rights issues has evidenced, consideration of human rights interests does not typically form part of the reasoning in investment disputes. Instead, investment arbitrators favour broad interpretations of treaty obligations, ${ }^{140}$ weigh state interests against investor interests through the lens of the impact on the investor, ${ }^{141}$ and traditionally eschew non-investment interests. Consequently, it is difficult to conclude that investment arbitration protects minority interests.

Countermajoritarian criticisms can also be assuaged by the provision of a legislative override, which is also absent in a system of investment arbitration. ${ }^{142}$ Unlike constitutional pronouncements of supreme courts, states faced with adverse decisions from investment arbitral tribunals need not revoke or amend the offending regulation. ${ }^{143}$ However, states must still compensate the investor who brought the action and they face possible lawsuits from other similarly situated investors as well. Because of these consequences, states may repeal the contested regulation. ${ }^{144}$ Furthermore, judicial review of the award is also very limited, and because review may occur in a third state, elected officials of the affected state may not necessarily be able to constrain the actions of the investment arbitral tribunal. ${ }^{145}$ In this sense, investment arbitration enjoys a type of judicial supremacy not associated with democracy as legislative checks on its decisions are very limited.

Alexander M. Bickel, The Least Dangerous Branch: The Supreme Court at the Bar of Politics (Indianapolis: Bobs-Merrill, 1962) at 16-17; Barry Friedman, "The History of the Countermajoritarian Difficulty, Part One: The Road to Judicial Supremacy” (1998) 73 N.Y.U.L. Rev. 333 at 354.

Friedman, ibid. at 353.

Chander, supra note 118 at 1203; Howse, supra note 112 at 58; Atik, supra note 127 at 458.

Commission on Human Rights, supra note 32 at 3-4; Van Harten, supra note 7 at 121; Rudolf Dolzer, “Indirect Expropriations: New Developments?” (2002) 11 N.Y.U. Envtl. L.J. 64 at 79-80: (under the "sole effect doctrine," arbitrators focus only on the regulation's impact on the investor rather than considering the broader context).

For example, tribunals have held that since foreign investors cannot participate in the democratic processes that allowed the adoption of the challenged measure, it may be reasonable for "nationals to bear a greater burden in the public interest than non-nationals": see Azurix, supra note 53 at para. 311; Tecmed, supra note 68 at paras. 121-22.

Ely, supra note 118 at 4.

Bickel, supra note 137 at 20.

See Ethyl, supra note 95; Gross, supra note 96.

Article 52(1) of the ICSID Convention, supra note 18, provides for the limited review of investment arbitral awards rendered under its jurisdiction. However, under non-ICSID rules, review is provided in the courts at the situs of the arbitration not in the courts of the affected state. Thus, when Mexico wanted to review the award against it in Mexico v. Metalclad Corp., 2001 BCSC 664, 89 B.C.L.R. (3d) 359 [Metalclad], although Mexico was the affected state, the courts of Canada reviewed the award as Vancouver was chosen as the situs of the arbitration. 


\section{Infusing Democratic Principles into InVestment ARbitration}

The implication of human rights issues in investment arbitration has transformed investment arbitration from a commercial dispute resolution mechanism into a governance system of a society's core values. Essentially, the investment arbitration process as it currently stands is not a suitable forum for the adjudication of the fundamental basic rights and liberties reflected in human rights. To reflect the public nature of the human rights issues implicated in investment arbitration, a greater need for democratic principles infused into the process is warranted. This can be accomplished by reducing the scope of investment arbitration and by instilling democratic principles into the investment arbitration process.

\section{A. REDUCing THE SCOPE OF INVESTMENT ARBitration}

In part, infusions of democracy are needed in the investment arbitration process because of its scope. If investment arbitration did not extend to the core values of a society, and stayed more within the purview of commercial issues, the criticisms of its democratic deficiencies would have less merit. One approach to restrain the scope of investment arbitration is to exempt human rights issues, wholly or in part, from a state's investment treaty obligations. For example, the U.S. has specified, in its recently concluded free trade agreements, that non-discriminatory regulations that protect legitimate public welfare objectives do not constitute expropriations. ${ }^{146}$ Similarly, both a recent Canadian investment treaty and Norway's model investment treaty exempt regulations that protect human, animal, or plant life, health, and investments in the cultural industries from the remainder of the treaty obligations. ${ }^{147}$ States have also curtailed the intersection of investment with human rights by limiting the nature of the investments covered by the treaty. Thus, the Republic of the Congo exempts investments relating to drinking water supply ${ }^{148}$ and Morocco exempts government aid used for national development programs and activities. ${ }^{149}$

States can also reduce the scope of investment arbitration by determining on a case by case basis which investment disputes they will submit to arbitration by withdrawing their ex

146 See e.g. United States-Australia Free Trade Agreement, 18 May 2004, Annex 11-B, art. 4(b), online: Office of the United States Trade Representative <http:/www.ustr.gov/trade-agreements/free-tradeagreements/australian-fta/final-text>; United States-Chile Free Trade Agreement, 6 June 2003, Annex 10-D, art. 4(b), online: Office of the United States Trade Representative <http:/www.ustr.gov/tradeagreements/free-trade-agreements/chile-fta/final-text>; Dominican Republic-Central America-United States Free Trade Agreement, 5 August 2004, Annex 10-C, art. 4(b), online: Office of the United States Trade Representative <http://www.ustr.gov/trade-agreements/free-trade-agreements/cafta-dr-dominicanrepublic-central-america-fta/final-text>; United States-Morocco Free Trade Agreement, 15 June 2004, Annex 10-B, art. 4(b), online: Office of the United States Trade Representative <http://www.ustr.gov/ trade-agreements/free-trade-agreements/morocco-fta/final-text>.

See e.g. Agreement between Canada and the Republic of Peru for the Promotion and Protection of Investments, 14 November 2006, arts. 10(1)(a), 10(6), online: Canada Treaty Information <http://treatyaccord.gc.ca/text-texte.asp?id=105078>; Norway Model Bilateral Investment Treaty, arts. 24, 27, online: Investment Treaty Arbitration <http://ita.law.uvic.ca/documents/NorwayModel2007.doc>. People's Republic of The Congo Concerning the Reciprocal Encouragement and Protection of Investment, 12 February1990, Senate Treaty Doc. No. 102-1, Annex.

149 Agreement between the Government of the United Kingdom of Great Britain and Northern Ireland and the Government of the Kingdom of Morocco for the Promotion and Protection of Investments, 30 October 1990, U.K.T.S. 2003 No. 7, art. 4(c). 
ante consent to arbitration. This is the approach followed in the Japan-Philippines free trade agreement, which does not provide the usual prior consent of the states authorizing investment arbitration. ${ }^{150}$ Alternatively, investment arbitration can be excluded as a forum for dispute resolution of investment disputes altogether. For example, the U.S.-Australia free trade agreement has created its own intra-state mechanism to resolve investment disputes. ${ }^{151}$

A third approach would be to constrain the scope of investment arbitration through judicial review of the investment arbitral award in domestic courts and thus reduce the process' countermajoritarian difficulty. Review of investment arbitral awards is generally restrictive, and for arbitrations conducted under ICSID rules, contained to arbitral forums. ${ }^{152}$ However, arbitrations not conducted under ICSID rules allow for review of the award in the national courts of the place of arbitration. ${ }^{153}$ National court reviews of arbitral awards are generally limited to procedural grounds, although they can be reviewed on the more substantive ground that the award conflicts with the state's public policy. ${ }^{154}$

For investment arbitral awards involving human rights issues, national court review on the grounds of compliance with public policy may be an appropriate avenue for further constraining the scope of investment treaties. Using the limited definition of public policy as "a genuine and sufficiently serious threat to one of the fundamental interests of society,"155 where an investment arbitral award compromises a human right, judicial review of the award can be used to nullify that portion of the award on the ground that it is contrary to public policy, as negating a human right is surely a threat to the fundamental interests of society. ${ }^{156}$ Even for those ICSID awards whose reviews are contained within the ICSID system, although the ICSID rules do not provide public policy as a ground for review, a public policy requirement can be incorporated when the party seeks enforcement of the award in a national court. ${ }^{157}$ In this way, national court review on public policy grounds can correct investment

Agreement between Japan and the Republic of the Philippines for an Economic Partnership, 9 Septemer 2006, art. 107(2), online: Ministry of Foreign Affairs of Japan <http://www.mofa.go.jp/region/asiapaci/philippine/epa0609/main.pdf>.

United States-Australia Free Trade Agreement, supra note 146, art. 21 (under this agreement a joint committee of U.S. and Australian elected representatives and their delegates supervise the arbitration process and arbitrators are selected from a roster of ten individuals selected by the state prior to the date of entry into force of the agreement). See supra note 145.

153 Van Harten, supra note 7 at 156.

United Nations, UNCITRAL Model Law on International Commercial Arbitration (Vienna: United Nations, 2008), art. 34(2)(b)(ii); Convention on the Recognition and Enforcement of Foreign Arbitral Awards, 10 June 1958, 330 U.N.T.S. 3, art. V(2)(b).

155 This is the definition adopted by the European Court of Justice and the World Trade Organization's General Agreement on Trade in Services (GATS): see Office of the United Nations High Commissioner for Human Rights, Human Rights and World Trade Agreements: Using General Exception Clauses To Protect Human Rights (New York: United Nations, 2005) at 10 [footnote omitted].

156 Even if the limited definition adopted by the European Court of Justice and the GATS is not adopted, state abuse of the public policy ground of review is unlikely as most states adopt a narrow view of public policy. In a six year study, the International Law Association found that public policy is rarely successful in preventing enforcement of international awards: see Audley Sheppard, "Public Policy and the Enforcement of Arbitral Awards: Should there be a Global Standard?” (2004) 1:1 Transnational Dispute Management 22.

157 Edward Baldwin, Mark Kantor \& Michael Nolan, “Limits to Enforcement of ICSID Awards” (2006) 23 J. Int'l Arb. 1 at 5-9 (noting that French courts have recognized public policy as part of the framework within which ICSID awards are enforced). 
arbitral awards that disregard human rights issues by limiting the award to reflect only the commercial nature of the dispute.

\section{B. Infusing Democratic Principles INTO THE INVESTMENT DISPUTE RESOLUTION PROCESS}

In addition to reducing the scope of investment arbitration, the protection of human rights can be facilitated by increasing public and governmental participation in the process and by institutionalizing the resolution of investment disputes. In this way, investment arbitration is moved farther away from the private model of international commercial arbitration whose characteristics it has traditionally embodied.

\section{INCREASED PARTICIPATION}

Because investment arbitration can result in constraints on sovereign authority and multimillion dollar damage awards that are paid out of public tax funds, the need for investment arbitration to incorporate principles of deliberative democracy is heightened. In particular, the process is sorely lacking in avenues for public participation and input.

Instilling greater transparency into the process would facilitate public access to information about the disputes, increase public confidence in the process, and, most importantly, provide for a measure of accountability for the arbitrators, giving them greater incentive to consider the public's interest and the value it ascribes to the measures in the dispute. ${ }^{158}$ To facilitate participation, an initial step should be to warrant compulsory publication of the pleadings and awards of all investment arbitrations. Although the ICSID ${ }^{159}$ and NAFTA state parties ${ }^{160}$ have taken considerable steps towards achieving this goal, investment arbitrations run under other arbitral institutions continue to treat arbitral documents with a high degree of confidentiality. ${ }^{161}$

Oral hearings of investment arbitrations should also be opened to the public. Incremental changes have been made in this regard, for example, by opening three NAFTA arbitration

Ronald B. Mitchell, "Sources of Transparency: Information Systems in International Regimes” (1998) 42 International Studies Quarterly 109; Eric Stein, "International Integration and Democracy: No Love at First Sight” (2001) 95 A.J.I. L. 489 at 494; Patti Goldman, “The Democratization of the Development of United States Trade Policy” (1994) 27 Cornell Int’l L.J. 631 at 648.

For most disputes, the ICSID publicizes the names of the parties to the dispute, the date of registration, and a brief description of the dispute, which are posted on the ICSID website. However, final awards are published only on the consent of the parties.

From 2002, all documents submitted to or issued by NAFTA tribunals are publicly available: see NAFTA Free Trade Commission, "Notes of Interpretation of Certain Chapter 11 Provisions" (31 July 2001), online: Foreign Affairs and International Trade Canada <http://www.international.gc.ca/tradeagreements-accords-commerciaux/disp-diff/NAFTA-Interpr.aspx?lang=en>.

161 For example, the International Chamber of Commerce and the Arbitration Institute of the Stockholm Chamber of Commerce do not publicize their disputes: see OECD Investment Committee, “Transparency and Third Party Participation in Investor-State Dispute Settlement Procedures” Working Papers on International Investment No. 2005/1 (2005) at 3, online: OECD <http://www.oecd.org/ dataoecd/25/3/34786913.pdf >. 
hearings to the public. ${ }^{162}$ The ICSID rules have also recently been revised to address this issue and now allow third parties to attend or observe the arbitral hearings. However, as the consent of the parties is required, public participation remains conditional. ${ }^{163}$

In contrast, public participation through the use of amicus curiae submissions has found greater acceptance at least in ICSID and NAFTA arbitrations. The ICSID rules allow tribunals to accept third party written submissions even without the consent of the disputing parties, and amicus' have been granted standing in a number of ICSID and NAFTA disputes. ${ }^{164}$ However, in addition to amicus, arbitrators should also be expected to consult with experts well versed in human rights issues to better understand the context of the investment dispute. Unlike amicus, these experts need not be granted standing and can simply provide either expert testimony or written submissions on their particular area of expertise. ${ }^{165}$

Finally, given the apparent agency costs between investment treaty negotiators and both elected representatives and the public, investment treaty negotiations should be aimed at greater inclusiveness. Negotiations of investment treaties require a notice and comment process in which the public and government representatives outside the trade and investment department are informed of the implications of investment treaties and are provided with an opportunity to offer their views. In addition, treaty negotiators should be required to consult with government officials in human rights-related departments to ensure that human rights protection is not curtailed in future investment treaties.

\section{INSTITUTIONALIZING INVESTMENT ADJUDICATION}

Adjudicative mechanisms are viewed as necessary to the functioning of democratic societies by virtue of their role as independent institutions, free from other branches of the state that can restrain majoritarian excesses as a means of protecting basic rights and liberties. Investment arbitration, however, cannot claim the same role as adjudicative mechanisms in democratic states due to both a lack of independence and its disinclination to protect basic rights and liberties.

In particular, the lack of independence of investment arbitrators clouds the legitimacy of their function. Lacking tenure and financial security, the need for investment arbitrators to bargain for new appointments may result in at least a perception of bias, which is compounded by the arbitrator's ability to engage in a multiplicity of roles in the arbitral

162 International Centre for Settlement of Investment Disputes, News Release, "Methanex v. United States of America NAFTA/UNCITRAL Arbitration Rules Proceeding” (8 June 2004), online: ICSID <http:// icsid.worldbank.org/ICSID/ICSID/ViewNewsReleases.jsp>; International Centre for Settlement of Investment Disputes, News Release, "United Parcel Service of America, Inc. v. Government of Canada NAFTA/UNCITRAL Arbitration Rules Proceeding” (7 December 2005), online: ICSID <http://www. worldbank.org/ICSID/ICSID/ViewNewsReleases.jsp>. See also Canfor v. United States of America, as discussed in OECD Investment Committee, ibid. at 10.

Arbitration Rules, supra note 20, r. 32.

Ibid., r. 37. For a list of disputes granting amicus standing, see supra note 27.

For example, in the General Agreement on Tariffs and Trade context, the World Health Organization provided an expert report on the issues in the dispute that was consulted by the Tribunal: see Thailand - Restrictions on Importation of and Internal Taxes on Cigarettes (Complaint by the United States) (1990), GATT Doc. DS10/R, 37th Supp. B.I.S.D. (1990) 200 at para. 52. 
system. ${ }^{166}$ Additionally, as investment arbitration does not require that any of the arbitrators be a national of the state whose regulation is under scrutiny, the accountability of the arbitrators to the public of the affected state for any decision they render is slight.

Realigning investment arbitration with democratic principles therefore requires the creation of a more institutionalized, rather than ad hoc, approach to adjudication. Institutionalizing investment adjudication could involve the establishment of a permanent arbitral body, roster, or court under which adjudicators can be granted both long-term tenure and financial security. States, as the representatives of the public, would make the appointments to the institutional body, with appointments extending for terms as lengthy as possible to encourage arbitrator independence. ${ }^{167}$ Most importantly, adjudicators should be prohibited from engaging in any activity incompatible with their independence or impartiality. To ensure a greater likelihood of value plurality in adjudication, appointments should also be aimed at the selection of both those who advocate investment interests and those with broader public interests.

An institutionalized approach to the resolution of investment disputes could also deter issues of regulatory chill by allowing states to obtain advisory interpretations on the legality of prospective legislation from the institution. ${ }^{168}$ Institutional interpretations would thereby prevent the threat of investment arbitrations from deterring state regulatory action. Institutionalizing investment dispute adjudication could also begin the process of allowing states to be able to initiate claims against investors or facilitate the mounting of affirmative defences. For example, Norway's model investment treaty requires investors to adhere to corporate social responsibility standards. ${ }^{169}$ Under an institutionalized approach, Norway could enforce this standard against investors or use it as an affirmative defence. ${ }^{170}$ Similarly, for states that are parties to treaties that cite sustainable development as a treaty objective, where human rights-oriented measures interfere with investments, states should be able to claim that the public good nature of the measure warrants a reduction in the total amount of compensation owed to the investor. In these ways, institutionalizing investment arbitration can work towards realigning the investor-centric emphasis of investment arbitration.

\section{CONCLUSION}

Given the limited corrective devices that can reassert the importance of the human rights values in investment arbitral awards, public control over investment arbitration appears to be limited. Although removing investment arbitration from domestic politics prevents investment policies from being captured by protectionist interests and provides greater protection for foreign investors, it also results in a loss of sovereign regulatory rights, a loss that appears greater than any benefits that ensue from the current structure.

Rau, supra note 28 at 521-22; Van Harten, supra note 7 at 172; Cosbey et al., supra note 31 at 6. Van Harten, ibid. at 182.

For example, NAFTA, supra note 10, art. 1131(2), provides for the issuance of binding interpretive statements.

Norway Model Bilateral Investment Treaty, supra note 147, art. 32.

Commission on Human Rights, supra note 32 at 31. 
The intersection of investment arbitration with human rights demands the alignment of the process with concepts of democracy. In effect, the rights provided to investors, although worthy of protection, should not be able to trump state measures aimed at addressing human rights issues derived through the democratic process. Mechanisms to counter the countermajoritarian difficulty are thus warranted, as are increased participation, by both the public and elected officials, and increased independence and accountability of the adjudicators of these investment disputes.

In a democratic society, only fundamental rights and liberties are privileged over all other forms of law. Accordingly, a need to protect human rights could override an otherwise democratic law. However, unlike human rights, foreign investment law is simply ordinary economic law. There is, thus, no reason why the law relating to foreign investment should be construed beyond the borders of democratic control. 